\title{
EVALUATION IN SCIENTIFIC ADVISORS' COMMENTARIES AS A MEANS TO DEVELOP STUDENTS' WRITING SKILLS
}

\author{
Albina Vodyanitskaya \\ Institute of Foreign Languages, Moscow City University (Russia)
}

\begin{abstract}
The paper focuses on evaluative means in scientific advisors' commentaries that have an educating power and serve to develop students' writing skills. A scientific advisor assumes various roles in the process of correcting and editing students' linguistic research related papers. The roles of editors, psychologists, reviewers, representatives of academic discourse are revealed in the commentaries that accompany a feedback that teachers provide their students with. The commentaries are of evaluative nature.
\end{abstract}

Keywords: Evaluation, writing skills, scientific advisor, commentaries, roles.

\section{Introduction}

Academic writing (further on - AW) has a long history as a genre and as a form of human intellectual activity.

Google Ngram Books graph (see below) shows that AW has been gradually gaining momentum among the scholars since 1960s.

Figure 1. The Occurrence of the Term “Academic Writing” in literature since 1800 (Google Ngram Books, electronic resource).

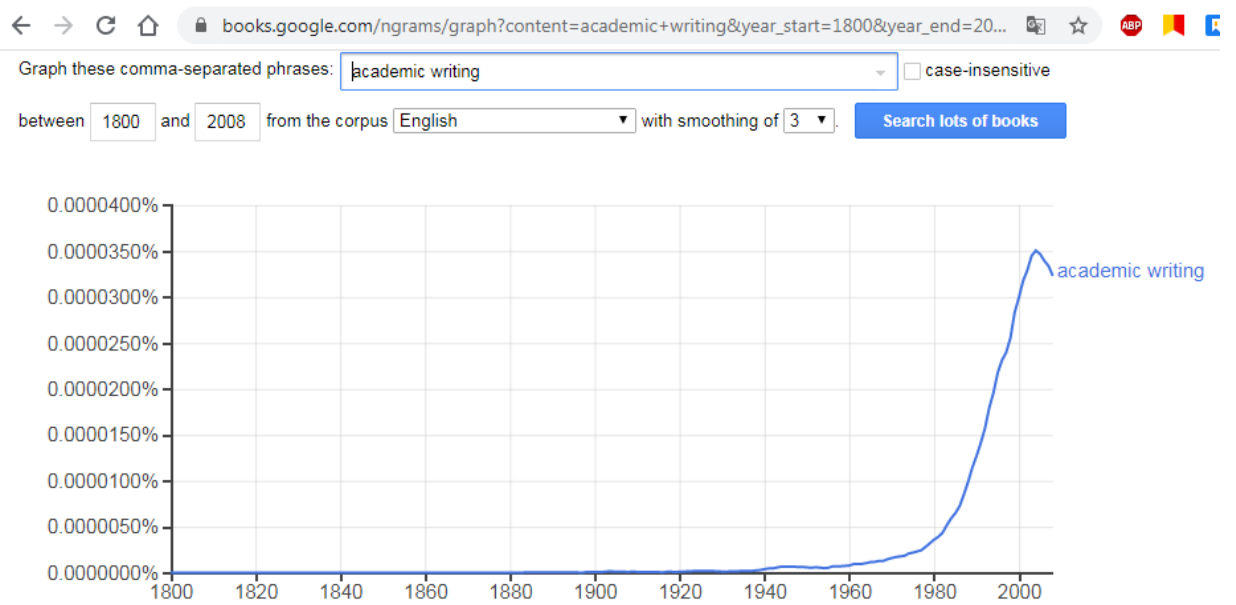

Since 1960s, scholarly research focusing on AW has increased dramatically (see, e.g., ScienceDirect resource, featuring 158,375 publications on AW (as of the beginning of January 2020))

AW enjoys a versatile and comprehensive research history and is being studied from various perspectives: scholars focus on existential aspects - e.g., the authors' as well as the readers' identities in AW (Hyland, 2001a; 2001b; 2002; 2010); they study AW through the prism of contemporary publication processes (Hyland, 2018); they examine specific linguistic features that are characteristic of AW (Vo, 2019). Teaching AW has also been in the focus of researchers' attention. Therefore, the nature of AW as regards to developing students' writing skills is studied (McGregor, 2018); the teaching AW across global contexts (Burgess \& Pallant, 2013) and across disciplines (Purser, Dreyfus \& Jones, 2020) is taken into account. Researchers undertake comparative analysis of students' and professional AW 
(Aull, Bandarage \& Miller, 2017); they focus on the nature of information in student notes (Siegel, Crawford, Ducker, Madarbakus-Ring \& Lawson, 2020) and on exemplars in students' writing (Carter, Salamonson, Ramjan \& Halcomb, 2018).

In this paper, I focus on developing students AW skills through the teacher's written feedback in the form of evaluative sentences.

\section{Methodology: Towards understanding the development of AW}

The process of creating research papers in the academe is a multidimensional phenomenon: students are empowered by their scientific advisors to write texts which correspond to the traditions of academic discourse, at the same time, writing research papers is a creative, individualized, process.

To help the learners develop their writing skills, scientific advisors comment on those parts of the research paper, which should be corrected, assuming various roles in the process of teaching.

The aim of the research was to reveal the implicit processes that underlie seemingly explicit process of providing feedback to students on their writing progress. Moreover, I focused on the persuasive techniques that teachers use to encourage and empower students to develop their writing skills. Linguistically, these techniques are based on evaluative lexis, while institutionally (from the point of view of academic discourse) they depend on the role that scientific adviser assumes when interacting with the students (the role of the representative of academic discourse society, the role of a psychologist and some such).

To study the mechanism of developing writing skills in students, 80 Russian theses and 107 course papers on linguistics with the commentaries from scientific advisors have been analyzed. For research purposes, my colleagues from the Department of Linguistics and Translation Studies (Institute of Foreign Languages, Moscow City University) let me analyse their commentaries on research papers of their students. Therefore, I had a verbalized feedback from 10 teachers. The number of commentaries amounts to 2100 utterances. The research focused on commentaries accompanied by a verbalized evaluation, when teachers expressed their attitude towards the way a particular section of the paper, a sentence, or a single word was written. In this paper, evaluation is regarded as "the broad cover term for the expression of the speaker's or writer's attitude or stance towards, view point on, or feelings about the entities or propositions that he is talking about" (Thompson \& Hunston, 2003). This definition is especially relevant for the research into AW, where the evaluation does not circulate around the good or the bad only: it covers relevancy, dynamism, depth, style and other aspects of a research that are evaluated. Therefore, the commentaries have been analysed based on semantics and the values of academic discourse, for "evaluation plays a key role in the construal of a particular ideology" (Hunston, 2002, 177).

When analyzing students' research papers the teachers rely on written academic discourse rules (see e.g. Suleimanova, 2017).

\section{Results}

The research has revealed that scientific advisors assume the role of the representatives of the academic discourse, when they encourage students to follow the ethics rules of the discourse community, demonstrating a respectful attitude to the scientists they quote. Therefore, the "dialogue with the Other in academic discourse" (Suleimanova, 2017; 2016) is developing. Markers of deontic modality are used in teachers' commentaries (one should be more explicit about the contribution of linguists in this field). Students' appraisal of their own papers (my paper is destined to be a role model for the papers in this field) are met by corrective commentaries shaping students' discourse identity. It is vital to feel a "humble servant of the discipline" (Hyland, 2010). There is a category of teachers' commentaries that are a reaction to students' misuse of evaluation, e.g. a first-year student wrote that this scientist has suggested too simple classification. The teacher advises the student to try to find something relevant in every classification and to avoid labeling linguists whose contribution to the field has long been acclaimed. In this case, the negative evaluation that is contained in the adjective simple (because the research of another linguist is evaluated) is corrected by the teacher in terms of academic discourse values and in terms of research ethics. Sometimes, when a positive evaluation of a linguist's contribution is used, teachers may correct students' use of evaluation. Thus, for example, when a student wrote that the researcher NN has developed a good typology, the teacher corrected the student by saying that we assess typology not in terms of good and bad, but in terms of its relevancy to the purposes of the research, moreover, by saying that the typology is good you place yourself in a position to judge the linguist's work, which is unacceptable from the point of view of academic discourse. In this case, the teacher encourages the student to explore the categories of acceptability and unacceptability in research processes. 
Assuming the roles of editors, teachers give extensive commentaries on the language use and style. Thus, e.g. when students analyse translations in the framework of translation studies research, they may use such evaluative sentences like this translation sounds drier than the other one. The teacher's correction - this translation sounds less expressive than the other one.

Various psychological issues blocking motivation are cured by positive evaluation (Perfect work!) which lessens the pressure and encourages students to continue researching, turning the teacher into a psychologist.

At the last stages of the research the teacher becomes mostly a reviewer, which is mirrored in the character of the evaluations used.

$85 \%$ of commentaries contain explicit verbalized evaluation, while in $15 \%$ evaluation is expressed in the form of advice to improve the passage. $99 \%$ of teachers' evaluations on first year course papers are negative, while $95 \%$ of teachers' commentaries in theses (written by the same students) contain positive evaluative means, for their writing skills have been drastically improved years 1 through 4.). In this case, we rely on the scientific adviser's review on a student's work and on the reviewer's feedback (for every student receives a feedback from an independent reviewer who evaluates the students thesis and comments on relevancy, style, compliance with academic discourse rules and some such).

\section{Conclusions: Towards the understanding of multidimensional character of developing AW skills}

Academic research starts for students when they make their first steps in the academe. They shape their discourse identity throughout the university life and AW contributes into this process significantly. It is the multidimensional character of AW that enables teachers to empower their students with professionally meaningful skills. The multidimensional character of AW reveals itself in the institutionally contextualized interactions between the student and his/her scientific advisor. First of all, importantly, scientific advisors develop students' ethic awareness, trying to reveal the values of the academe to the researcher-beginners, the students' understanding of the importance of these values reveals itself in their written texts - when they cite scholars, when they respectfully evaluate scientists' theories, contributions and typologies. Secondly, teachers promote life-long-learning to their students (Vodyanitskaya, 2018), for the latter see that there is always a room for improvement in writing. Thirdly, students become the members of discourse society, for they learn to analyze and take into account their teachers' evaluations and judgements, polishing their research skills. Developed AW skills outreach academic environment, for students develop linguistically (learning to verbalize their research analysis) and professionally. Their self-esteem is boosted in the process of mastering writing as well as speaking skills (Suleimanova, Yaremenko \& Vodyanitskaya, 2018). Scientific advisors' commentaries have, therefore, pedagogical, cultural, ethical, discoursive, psychological and linguistic impact. They change over time with the changes in students' writing. The roles they assume also change over time - with the development of the student's writing skills, teacher's roles also develop.

What is relevant, such commentaries are aimed at developing understanding in academic discourse (for more on understanding in academic discourse see Suleimanova 2013) and the final presentations of students' research results show that this understanding has been mutual.

\section{Acknowledgements}

I owe a debt of gratitude to Doctor of Philology, Professor, Professor of Moscow City Teacher Training University, Chairperson of the Department for Linguistics and Translation Studies Olga Arkadyevna Suleimanova for her ongoing support, guidance and stimulating discussions that inspire me to life-long learning.

\section{References}

Aull, L. L., Bandarage, D. \& Miller, M. R. (2017). Generality in student and expert epistemic stance: A corpus analysis of first-year, upper-level, and published academic writing, Journal of English for Academic Purposes, Vol. 26, 29-41.

Burgess, S., Pallant, A. (2013). Teaching academic writing in Europe: multilingual and multicultural contexts, Supporting Research Writing: Roles and Challenges in Multilingual Settings, Chandos Information Professional Series, 19-38. 
Carter, R., Salamonson, Y., Ramjan, L. M. \& Halcomb E. (2018). Students use of exemplars to support academic writing in higher education: An integrative review, Nurse Education Today, Vol. 65, pp. 87-93.

Google Ngram Books: Academic Writing Search Results. Retrieved from: https://books.google.com/ngrams/graph?content=academic+writing\&year_start $=1800 \& y e a r \_e n d=$ $2000 \&$ corpus $=15 \&$ smoothing $=3 \&$ share $=\&$ direct_url $=\mathrm{t} 1 \% 3 \mathrm{~B} \% 2 \mathrm{Cacademic} \% 20 \mathrm{writing} \% 3 \mathrm{~B} \% 2 \mathrm{Cc}$ 0\#t1\%3B\%2Cacademic\%20writing\%3B\%2Cc0

Hunston, S. \& Thompson, G. (2003). Evaluation in Text: Introduction. In S. Hunston \& G. Thompson (Eds) Authorial Stance and the Construction of Discourse. Oxford: Oxford University Press.

Hyland K. (2001b). Humble servants of the Discipline: Self-Mention in Research Articles. English for Specific Purposes, Vol. 20, 207-226.

Hyland, K. (2001a). Bringing in the Reader: Addressee Features in Academic Articles. Written Communication, Vol. 18, No. 4, 549-574.

Hyland, K. (2002). Authority and Invisibility: Authorial Identity in Academic Writing, Journal of Pragmatics, Vol. 34, 1091-1112.

Hyland, K. (2002). Options of Identity in Academic Writing. ELT Journal, Vol. 56, No. 4, 351-358.

Hyland, K. (2010). Community and Identity in Applied Linguistics, Written Communication, Vol. 27 (2), $159-188$

Hyland, K. (2010). Constructing Proximity: Relating to Readers in Popular and Professional Science. Journal of English for Academic Purposes, Vol. 9, 116-127.

Hyland, K. (2018). Academic Publishing: Issues and Challenges in the Construction of Discourse. Oxford: Oxford University Press.

McGregor, S. L. (2018). Understanding and Evaluating Research: A Critical Guide. London: Sage.

Purser, E., Dreyfus, S. \& Jones, P. (2020) Big ideas \& sharp focus: Researching and developing students' academic writing across the disciplines, Journal of English for Academic Purposes, Vol. 43.

Siegel, J., Crawford, M.J., Ducker, N., Madarbakus-Ring, N. \& Lawson, A. (2020). Measuring the importance of information in student notes: An initial venture. Journal of English for Academic Purposes. Vol. 43, 1-12.

Suleimanova, O. A. (2016). Dialog s Drugim v akademicheskom diskurse. Dialog kul'tur. Kul'tura dialoga: v poiskah peredovyh sociogumanitarnyh praktik: Materialy Pervoj mezhdunarodnoj konferencii. Pod obschej redakciej E. G. Tarevoj, L. G. Vikulovoj. Moskva: Yazyki narodov mira, 539-547. (The dialogue with the Other in academic discourse)

Suleimanova, O. A. (2017). K voprosu o normativnosti pis'mennogo akademicheskogo diskursa. VestnikMoskovskogo gorodskogo pedagogicheskogo universiteta. Seriya: Filologiya. Teoriya yazyka. Yazykovoe obrazovanie, Vol. 2 (26), 52-61. (The Norm in written academic discourse)

Suleimanova, O. A., Yaremenko, V. I. \& Vodyanitskaya, A. A. (2018) Boosting Students' Self-Esteem Through Training Them in Speaking Skills. Iceri 2018 Proceedings, 10409-10413.

Suleimanova, O.A. (2013). Linguistic Meta-Language as a Basis for Communication. Understanding: Abstract and Control. Understanding by Communication. Cambridge: Cambridge Scholars Publishing, 70-79.

Vo, S. (2019). Use of lexical features in non-native academic writing. Journal of Second Language Writing, Vol. 44, 1-12.

Vodyanitskaya, A. (2018). Verbal Evaluation as a Getaway to Inspire Life-long Learning in Students. Edulearn 2018 Proceedings, 5314-5318. 